\title{
THE EFFECT OF ORALLY ADMINISTERED HYDRO- CHLORIC ACID UPON THE GASTRIC CONTENTS IN NORMAL INDIVIDUALS AND IN PATIENTS WITH ACHLORHYDRIA*
}

\author{
BY RICHARD A. KERN, EDWARD ROSE AND J. HAROLD AUSTIN
}

(From the John Herr Musser Department of Research Medicine of the University of Pennsylvania and the Medical Division of the University Hospital

(Received for publication May 3, 1926)

The adequacy of the customary dose of dilute hydrochloric acid given to patients with gastric anacidity has been questioned by a number of observers. In 1907, Leo (1) found that a dose of hydrochloric acid corresponding to $2.5 \mathrm{cc}$. (U. S. P. dilute) was the smallest that was ever followed by free hydrochloric acid in the gastric contents, while greater doses, up to a maximum of $12 \mathrm{cc}$., at times failed to produce free acid. In 1918, Crohn (2) observed that small single doses of hydrochloric acid given to achlorhydria patients were promptly neutralized, and only after the administration of larger doses (1.6 to $2.6 \mathrm{cc}$.) was free hydrochloric acid found to be present for a time in the fractionally removed gastric contents. For many years the constant finding of gastric anacidity in cases of pernicious anemia has led to speculation as to the possible etiologic relation of achlorhydria to this disease. Hurst (3), who favors such a relationship, has recently emphasized the importance of overcoming the anacidity by giving 4 to $6 \mathrm{cc}$. of dilute hydrochloric acid as a routine dose. His co-worker, Shaw (4) in a study of five cases of pernicious anemia, found, by fractional gastric analysis, little or no free hydrochloric acid after the administration of $4 \mathrm{cc}$. of dilute hydrochloric acid, while 8 cc. usually gave sufficient free acid to have a germicidal effect. Vanderhoof (5), in a clinical study of seven cases of combined sclerosis with achlorhydria but without anemia, reported marked clinical

* Read in abstract before the Association of American Physicians at Washington, D. C., May, 1925. 
improvement after the continued administration of 4 to $8 \mathrm{cc}$. of dilute hydrochloric acid, and emphasized the importance of adequate dosage of acid.

It, therefore, occurred to us to study in detail the effects of various doses of hydrochloric acid upon the gastric contents of individuals with and without achlorhydria, and to attempt to determine the fate of the acid given.

In a study of this problem, a number of factors must be taken into consideration. In the first place, it has been amply shown (Bennett and Ryle (6), Talbot (7), Rehfuss et al. (8)) that wide variations in both free and total acidity may occur in supposedly normal individuals. The mechanism by which the gastric acid is neutralized is a complex one, and by no means completely understood, involving as it does in addition to neutralization by swallowed saliva and mucus and possibly dilution by gastric secretion, also the regurgitation of alkaline duodenal contents, and the secretion of an alkaline fluid by the pars pylorica, as suggested by Jvy and Oyama (9). In order to determine the part played by some of these factors, we studied in addition to total and free acid in the gastric contents, the hydrogen-ion concentration, the totalchloride concentration, peptic activity, and in some instances the tryptic activity.

It must be stated at the outset that the various values obtained in gastric contents removed by the fractional method are not advanced as representative of a uniform composition of the stomach contents of that part of the stomach (the antrum) from which we tried as a rule to remove our samples. We do believe, however, that the variations of these values, and the curves derived therefrom, can give some information as to the normal and pathological physiology of the stomach, and the influence on these processes of a therapeutic agent such as hydrochloric acid.

\section{MATERIAL}

Studies were made on twenty-one patients. Of these, seven had no gastrointestinal symptoms, and have been grouped as "normal cases;" six of them showed normal gastric findings, and one was found to have hyperacidity. There was also included in this group one case of hypoacidity, a patient with possible alcoholic gastritis. The 
remaining thirteen patients had gastric anacidity, due in nine instances to primary pernicious anemia, in one to a gastric ulcer, proven at operation and possibly syphilitic in origin; in another associated with suspected syphilis of the stomach, while in two patients there was an idiopathic anacidity. One of the latter had a diaphragmatic hernia, while the other suffered from colitis. In nineteen individuals, a fractional gastric analysis was done, with determinations of free and total acidity, $\mathrm{pH}$, and in selected samples, chloride concentration and peptic and tryptic activity. In fourteen patients (four "normal" and ten anacidity cases), such observations were also made after the administration, with the test meal, of dilute hydrochloric acid, U.S. P., in amounts varying from 1 to $14 \mathrm{cc}$.

\section{METHODS}

The test meal used consisted of two slices of wheat bread with two glasses (about $360 \mathrm{cc}$.) of water. The acid, when given, was usually swallowed by the subject, but in a few instances the mixture of acid and water was introduced into the stomach through the tube, the bread being swallowed first. Specimens of gastric content were withdrawn at varying time intervals, as shown in the tables below. An attempt was made in every instance to pass the tube into the antrum of the stomach.

Most of the samples removed, up to one hour after the meal, contained undigested bread, and many were also mixed with varying amounts of mucus and saliva. Accordingly, in every instance, except when the samples were unmixed with bread particles, mucus or saliva, they were centrifuged, and the supernatant liquid used for all determinations.

One or $2 \mathrm{cc}$. of the sample were titrated with $0.02 \mathrm{~N} \mathrm{NaOH}$, dimethylamidoazobenzol being used as the indicator for free hydrochloric acid, with the permanent yellow taken as end-point, and an alcoholic solution of phenolphthalein as the indicator for total acidity, with the first permanent pink taken as the end-point. The free and total acidity were expressed, as usual, in terms of cubic centimeters of $0.1 \mathrm{~N}$ acid per $100 \mathrm{cc}$. of gastric content:

An approximate indication of the $\mathrm{pH}$ was obtained by colorimetric comparison with standard buffer solutions, using appropriate indi- 
cators. The following solutions were made (Clark (10)), $\mathrm{pH} 1.5$ and

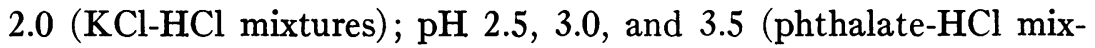
tures), $\mathrm{pH} 4.0,4.5,5.0$ and 5.5 (sodium acetate-acetic acid mixtures); $\mathrm{pH}$ 6.0, 6.5, 7.0 and 7.5 (phosphate mixtures). The indicators used were thymol blue ( $\mathrm{pH} 1.0$ to 2.5 ), methyl orange ( $\mathrm{pH} 3.0$ to 5.0 ), brom-cresol-purple ( $\mathrm{pH} 5.0$ to 7.0), and phenol red $(\mathrm{pH} 7.0+$ ).

One drop of the indicator was added to $0.8 \mathrm{cc}$. of the sample of gastric content and to $0.8 \mathrm{cc}$. each of two or more standard solutions with which the sample was to be compared, each portion of standard solution and the gastric content being placed on a porcelain spot-plate. The standard solution showing the color nearest to that of the gastric sample was taken as the colorimetric $\mathrm{pH}$ of the stomach content. A reading accurate to $0.5 \mathrm{pH}$ was considered adequate. It is recognized that this colorimetric $\mathrm{pH}$ may differ from the true $\mathrm{pH}$ of the gastric contents by at least 1.0 because of protein and salt error. The variations in $\mathrm{pH}$ in which we are interested are, however, so gross that this crude index of gastric $\mathrm{pH}$ has some value.

Determinations of the chloride content were made on the supernatant fluid of the centrifuged gastric samples by the Volhard method. The results are expressed in terms of milliequivalents per liter, as are the results of titration for free hydrochloric acid and total acidity.

Pepsin and trypsin determinations were made by the method of Itakura (11) which is described as a modification of the Fuld-Gross method, and is done as follows:

Pepsin. A casein stock solution is made by dissolving 0.15 gram of dry casein in $50 \mathrm{cc}$. of $0.1 \mathrm{~N} \mathrm{NaOH}$, heating, while stirring, on a waterbath to $80^{\circ} \mathrm{C}$., placing in a vessel of cold water, and then bringing to $100 \mathrm{cc}$. volume with distilled water. $10 \mathrm{cc}$. of the above solution are pipetted into a $100 \mathrm{cc}$. volumetric flask containing $30 \mathrm{cc}$. of $0.1 \mathrm{~N} \mathrm{HCl}$, brought to the mark with distilled water, and shaken. The resulting solution is an almost clear liquid which may be preserved by the addition of a small amount of chloroform.

An acetate mixture is used to precipitate the undigested casein, stop enzyme action, and prevent the precipitation of bile acids. It is prepared by titrating 100 cc. of 15 per cent $\mathrm{NaOH}$ against litmus paper with 6 per cent acetic acid. After neutralization, nine-tenths the volume of acid used in the titration is added.

To obtain an approximate idea of the degree of peptic activity in the sample of stomach contents, $0.1,0.01,0.001$, and $0.0001 \mathrm{cc}$. of the sample obtained by serial dilution with $0.01 \mathrm{~N} \mathrm{HCl}$ are placed in five tubes (preferably $1 \mathrm{~cm}$. in diameter 
and $10 \mathrm{~cm}$. in length), and each is brought to $1 \mathrm{cc}$. by the addition of $0.01 \mathrm{~N} \mathrm{HCl}$. Two cubic centimeters of the casein solution are added to each tube, which makes the final concentration of casein 0.01 per cent, the tubes are stoppered, and placed in a water bath at $38^{\circ} \mathrm{C}$. for a convenient time. (This is usually from one-half to one hour.)

The digestion of the casein occurs in a medium the $\mathrm{pH}$ of which is approximately 1.7 .

At the end of the half hour or hour period the tubes are removed from water bath, five or six drops of the acetate solution are added to each tube, and they are cooled quickly to room temperature in cold water. The undigested casein will be precipitated in a few minutes, making.the solution opaque or hazy, while clarity of the solution is taken as an indication of complete casein digestion. Incubation with the above dilutions of gastric juice gives an idea of the lowest concentration at which digestion is completed, in the time allowed. For a more accurate reading a second series of dilutions of gastric juice is now made--between the dilutions which in the first incubation showed a change from cloudiness to clearness.

The test permits the selection of that critical tube which contains the lowest concentration of gastric juice sufficient to digest completely the standard casein solution in a given time interval, and this critical tube is taken as representing a given concentration of pepsin. Itakura defines a unit concentration of pepsin as that concentration which will digest the standard 0.01 per cent casein solution at $38^{\circ} \mathrm{C}$. and under the condition of the test in one hour. He found that the concentration of pepsin required was inversely proportional to the time allowed for digestion. He expressed the pepsin concentration in the original gastric juice or unknown solution as $\log \mathrm{P}$ defined as follows:

$$
\log P=\log \frac{3}{E T}
$$

where $E=$ cubic centimeters of gastric juice (or unknown solution) contained in the critical tube of the test (total content $3 \mathrm{cc}$.) and $T=$ time, in hours, of incubation at $38^{\circ} \mathrm{C}$.

It must be remembered that $\log P$, the expression for peptic activity, being logarithmic, a variation in $\log P$ of 1.0 represents a ten fold variation in the measured peptic concentration.

For determination of trypsin the method is the same, except that the casein solution is made as follows:

To $10 \mathrm{cc}$. of the casein stock solution in a $100 \mathrm{cc}$. volumetric flask are added 50 cc. of distilled water and a drop of 0.5 per cent phenolphthalein solution $(0.5$ gram in $100 \mathrm{cc}$. of 43 per cent alcohol) and this is titrated carefully with $0.1 \mathrm{~N}$ hydrochloric acid until the rose-red color disappears. The mixture is then made up to the mark with distilled water. In preparing the tubes for incubation, the dilution of gastric content is made up to $1 \mathrm{cc}$. by diluting with distilled water after 
neutralization of the gastric content. The final mixture should have a $\mathrm{pH}$ of about 7.0. In testing for trypsin it is therefore necessary to neutralize acid present by adding the proper amount of sodium hydroxide. The method is similar in all other respects to the one used for pepsin determination.

For details of the methods, and the derivation of the equation used, the reader is referred to Itakura's article.

CONTROL OBSERVATIONS WITHOUT ACID ADMINISTERED

\section{Normal individuals}

Studies were first made in a series of so-called normal individuals. The examinations included a fractional gastric analysis, with determinations of total acidity, free hydrochloric acid, $\mathrm{pH}$ and, in selected instances, chloride content and peptic activity. In four of the eight cases so studied, the fasting content showed no free hydrochloric acid, while in the other four, free hydrochloric acid was present in the fasting content. The results in these two groups are tabulated separately.

\section{No free $\mathrm{HCl}$ in fasting contents}

Table 1 gives the figures obtained in the four cases showing no free hydrochloric acid in the fasting content.

Analysis of table 1 shows:

1. The free hydrochloric acid and total acidity curves conform to average normal values, reaching a maximum at between 45 and 90 minutes.

2. $\mathrm{pH}$ decreased progressively up to 60 to 75 minutes in all four cases; $\mathrm{pH}$ variations roughly paralleled those of the free hydrochloric acid.

3. Chloride content, in the two cases studied, showed a progressive increase, reaching maximal values at 90 minutes, the time of the last determination.

4. Peptic activity, in the one case studied, was within normal limits.

\section{With free $\mathrm{HCl}$ in fasting contents}

Table 2 gives the findings of similar studies in the subjects showing free hydrochloric acid in the fasting content.

Analysis of table 2 shows: 


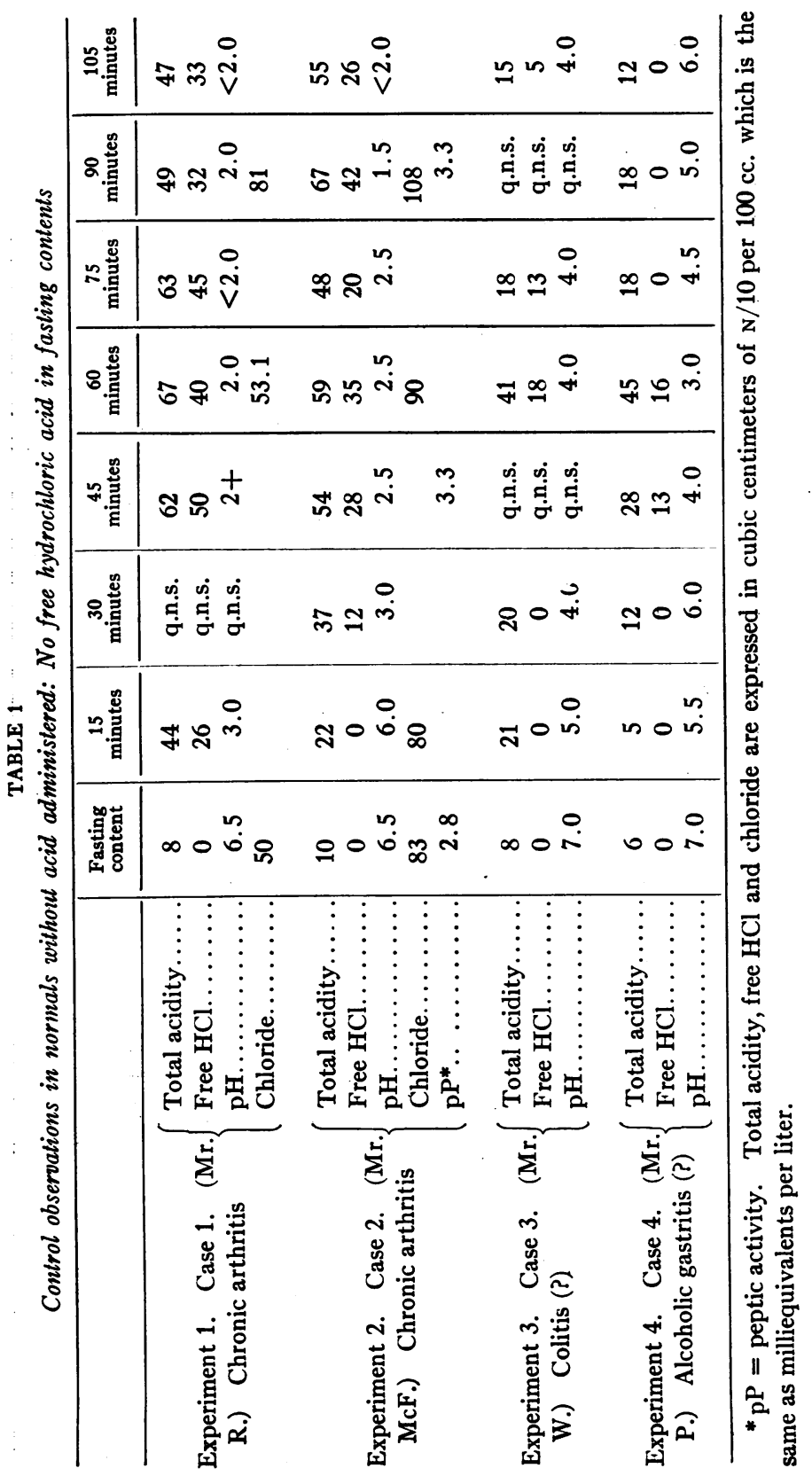




\begin{tabular}{|c|c|c|c|c|c|}
\hline & 象 & 111 & 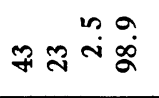 & 111 & 111 \\
\hline & 常| & 111 & in న్ల & 111 & 111 \\
\hline & 䓛 & 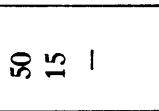 & 11 & 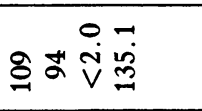 & $\infty \approx \tilde{\sigma} \stackrel{0}{V}$ \\
\hline & \& & 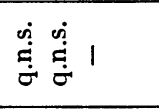 & ำ ํำ & $\& \& \stackrel{0}{\mathrm{i}}$ & oิ in $\stackrel{n}{\sim}$ \\
\hline & 路苞| & 8 m $\underset{\mathrm{m}}{\mathrm{v}}$ & oิ in ํํㅇㅇㅛ & ț욜 & $g \mp \stackrel{0}{v}$ \\
\hline & $8 \stackrel{0}{n}$ & $\tilde{ᄋ} 8 \stackrel{0}{\mathrm{~V}}$ & 冓 & 9 욜 & సᄋํㅇ \\
\hline 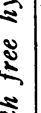 & 蚂 & న స & 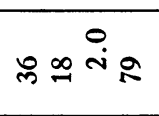 & $\stackrel{O}{\infty} \stackrel{\stackrel{i}{V}}{\vec{v}}$ & 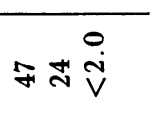 \\
\hline & 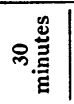 & 舟年 & $\infty \stackrel{0}{\sim} \underset{v}{\sim}$ & $\vec{\infty}=\stackrel{0}{\stackrel{0}{V}}$ & $m \vec{m} \underset{\sim}{\sim}$ \\
\hline & 跣 & $\vec{a}$ in $\stackrel{0}{v}$ & $\tilde{\sim} \approx \tilde{m}$ & 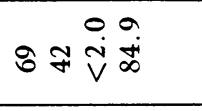 & $\ddot{\sim} \infty \stackrel{0}{\sim} \stackrel{0}{\sim}$ \\
\hline 5 & 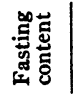 & $\vec{a} \stackrel{0}{i} \stackrel{i}{v}+$ & 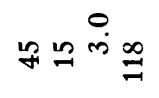 & $\stackrel{\sim}{2} \pm \stackrel{0}{i} \vec{j}$ & $\underline{\Omega}=\stackrel{\dot{0}}{\dot{\sigma}}$ \\
\hline & & 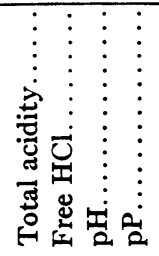 & 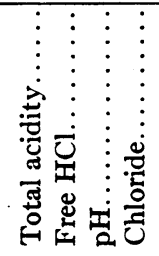 & 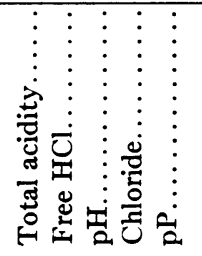 & 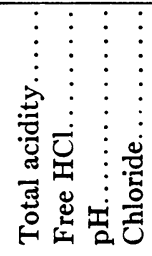 \\
\hline s & & 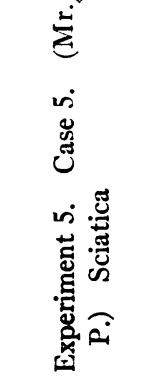 & 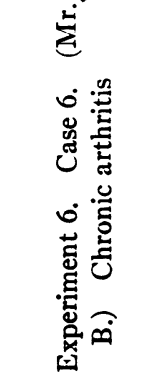 & 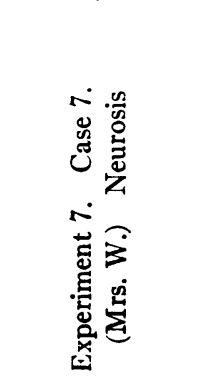 & 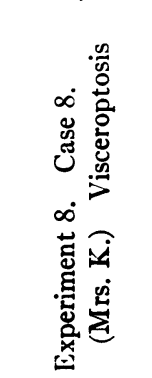 \\
\hline
\end{tabular}


1. Both free hydrochloric acid and total acidity curves in the cases showing free hydrochloric acid in the fasting content tend to rise higher than those with no free hydrochloric acid in the fasting content.

2. $\mathrm{pH}$ was low throughout, falling in the first thirty minutes, and usually rising slightly thereafter. $\mathrm{pH}$ variations again roughly paralleled those of the free hydrochloric acid.

3. In two cases the chloride concentration increased progressively and in a third case was high throughout.

4. Peptic activity, in the two cases studied, was greater than in the case in the previous group; it did not, in the one case in which it was tested at intervals increase parallel with the acidity, but, in fact, decreased slightly.

\section{Patients with achlorhydria}

Similar studies were then made thirteen times in twelve patients with achlorhydria. Eight were cases of primary pernicious anemia, two probably syphilis of the stomach, while in two there was no obvious cause for the achlorhydria. The figures are given in table 3 .

Analysis of table 3 shows:

1. The total acidity, except in case 17, did not exceed 25 milliequivalents; the variation in total acid was not consistent, but tended to fall slightly in most instances.

2. No free hydrochloric acid was present in any case.

3. $\mathrm{pH}$ remained fairly constant: in all except case 17 it was 5.5 or above.

4. Chloride concentration in the fasting content was within the range observed in normal individuals but was considerably less than in the normal during the subsequent periods. In all instances there was a primary fall in chloride concentration, probably due to dilution of the gastric content by the entrance of the test meal, followed by a rise of varying degree.

5. Peptic activity was frequently diminished to 1.5 and when studied at intervals showed practically no variation. In one instance, case 17 , a patient with syphilis of the stomach, the peptic activity was normal. It is interesting to note that in this case alone were there high values for total acidity, and a $\mathrm{pH}$ close to 3.0 .

6. Trypsin was present in all five cases in which a test for it was 


\begin{tabular}{|c|c|c|c|c|c|c|}
\hline & 墕 & $=0$ in & $\infty 00$ & a 0 in & $=0 \stackrel{\circ}{0} 1 \stackrel{+}{i}$ & \#0 \\
\hline & \&.苞 & $=00$ & no 00 & $000^{n}$ & $\begin{array}{ll}\pi \\
0 \\
0\end{array}$ & 이 $0 \stackrel{\dot{g}}{\dot{\sigma}}$ \\
\hline & 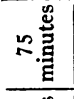 & 웅 & a $0 \stackrel{0}{0}$ & 2001 & 00 in & $\cong 0 \begin{array}{lll}0 & 0 & 0 \\
0\end{array}$ \\
\hline & 8. & $m 0 \stackrel{0}{\circ}$ & 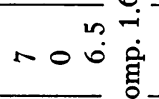 & $=00$ & $\simeq$ 용 & $\approx 0 \stackrel{0}{\circ}$ \\
\hline & 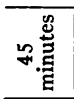 & 웅ㅇํ & $000^{n}$ & $\simeq 0$ in & $00 \stackrel{1}{0} 0^{n}$ & 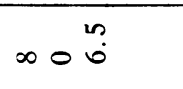 \\
\hline 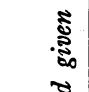 & 异䓵 & $=0 \stackrel{n}{0}$ & $100^{n}$ & $\Rightarrow 0$ in & 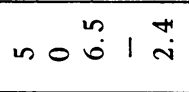 & 我 \\
\hline $\begin{array}{l}\tilde{z} \\
\dot{z} \\
\dot{z}\end{array}$ & 蒫 & 111 & $\begin{array}{lll}1 & 1 & 1\end{array}$ & 111 & $\begin{array}{llll}1 & 1 & 1 & 1\end{array}$ & $\begin{array}{llll}1 & 1 & 1 & 1\end{array}$ \\
\hline 节 & 哫 & $=10$ & $a 00^{n}$ & $=0 \stackrel{0}{\circ}$ & - 0 in & no $0 \dot{0} \ddot{q}$ \\
\hline के & 㺃 & 111 & 111 & 111 & $\begin{array}{llll}1 & 1 & 1 & 1\end{array}$ & $\begin{array}{llll}1 & 1 & 1 & 1\end{array}$ \\
\hline 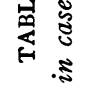 & 的蛋 & $\begin{array}{lll}1 & 1 & 1\end{array}$ & $\begin{array}{lll}1 & 1 & 1\end{array}$ & 111 & $\begin{array}{llll}1 & 1 & 1 & 1\end{array}$ & $\begin{array}{llll}1 & 1 & 1 & 1\end{array}$ \\
\hline है & 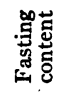 & no & 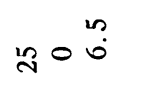 & noํำ & 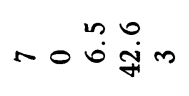 & $m 01 \stackrel{\infty}{\rightarrow} m$ \\
\hline î̀ & & 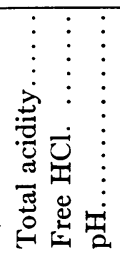 & 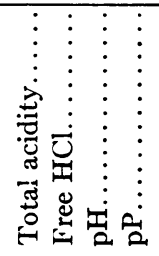 & 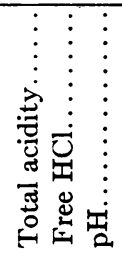 & 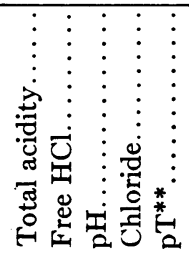 & 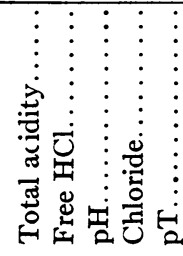 \\
\hline & & 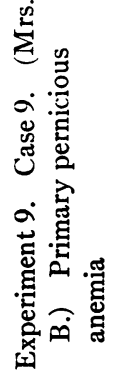 & 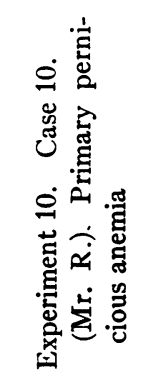 & 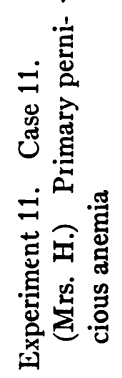 & 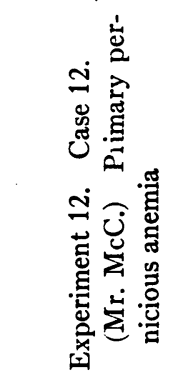 & 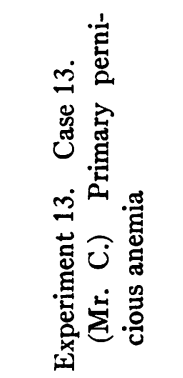 \\
\hline
\end{tabular}




\begin{tabular}{|c|c|c|c|c|c|}
\hline 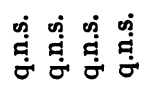 & 111 & $\approx 0$ & กำ กิ & & $a 00^{n} 11$ \\
\hline 宅 & 이웅 & $\infty 0$ & 용 i & & - \\
\hline n & $=00^{n}$ & $\infty 0$ & จ요 & & $a_{0} \stackrel{0}{0} 1 \stackrel{0}{i}$ \\
\hline 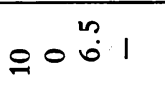 & 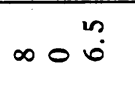 & 䓪o & i ० मnं & & 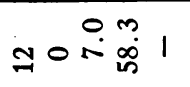 \\
\hline noํํํำ & 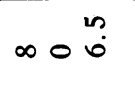 & 迎o & 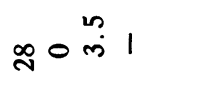 & & 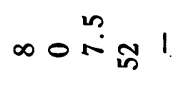 \\
\hline $00 \stackrel{0}{1}$ & n 0 in & $\because 0$ & o & & $a 00 \begin{array}{lll}n & 0 & 1\end{array}$ \\
\hline $\begin{array}{llll}1 & 1 & 1 & 1\end{array}$ & 111 & 11 & $\begin{array}{llll}1 & 1 & 1 & 1\end{array}$ & - & $\begin{array}{lllll}1 & 1 & 1 & 1 & 1\end{array}$ \\
\hline $00 \stackrel{n}{0}$ & nم & $\stackrel{\infty}{\sim} 0$ & सु० & $00 \tilde{n}$ & $=0 \stackrel{0}{0} \stackrel{i}{i}$ \\
\hline $\begin{array}{llll}1 & 1 & 1 & 1\end{array}$ & 111 & 11 & 1111 & n용 & $\begin{array}{lllll}1 & 1 & 1 & 1 & 1\end{array}$ \\
\hline $\begin{array}{llll}1 & 1 & 1 & 1\end{array}$ & 111 & 11 & $\begin{array}{llll}1 & 1 & 1 & 1\end{array}$ & o oñ & $\begin{array}{lllll}1 & 1 & 1 & 1 & 1\end{array}$ \\
\hline कor & a & $\infty 0$ & 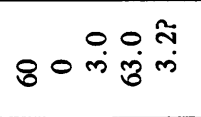 & 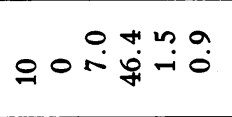 & 엄요 1 \\
\hline 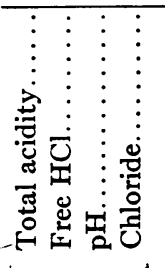 & 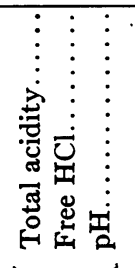 & 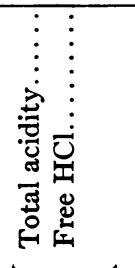 & 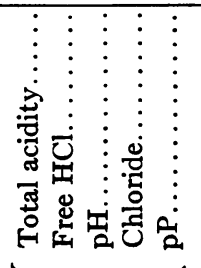 & 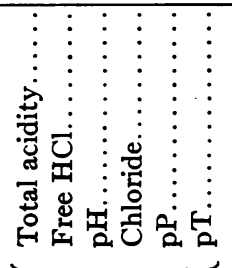 & 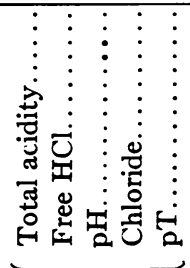 \\
\hline 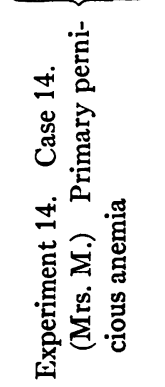 & 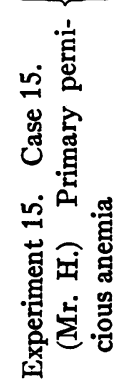 & 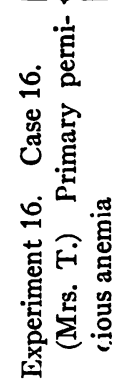 & 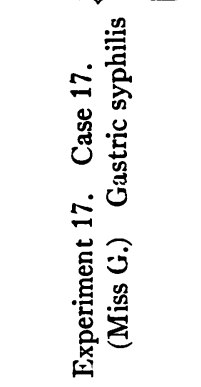 & 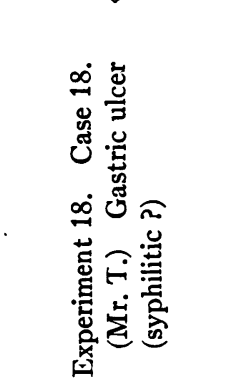 & 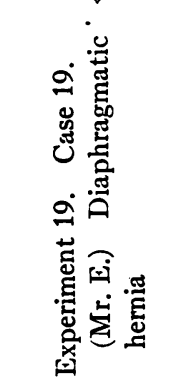 \\
\hline
\end{tabular}




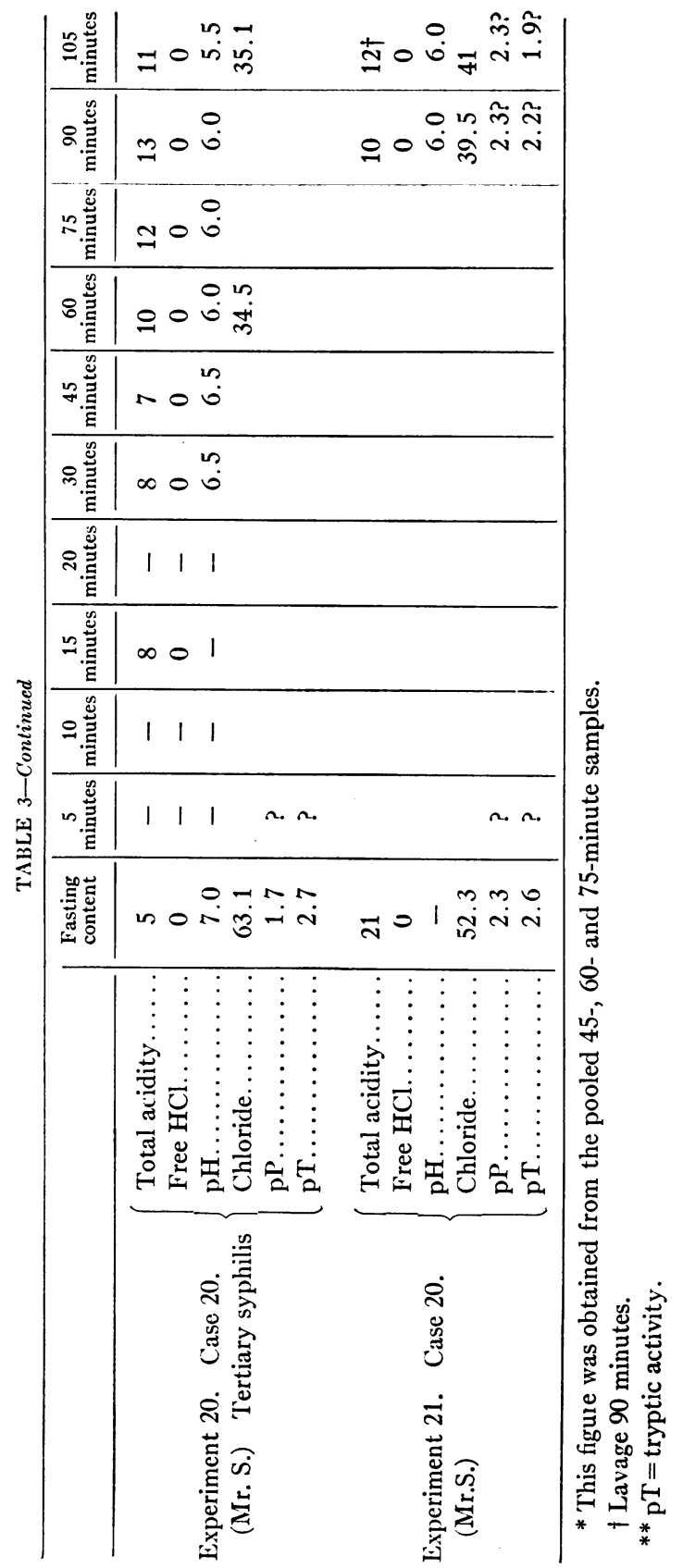


made. The greatest activity was noted in the fasting content, falling somewhat thereafter. This would point to duodenal regurgitation as a regular phenomenon in cases of anacidity. How regularly this is also true in the normal is under study at present.

\section{DISCUSSION OF PRELIMINARY OBSERVATIONS}

The foregoing observations on gastric acidity in normal individuals are in accord with the findings of previous investigators. Our figures fall well within the wide limits within which free hydrochloric acid in supposedly normal individuals may vary according to Bennett and Ryle (6), Talbot (7), and Crohn and Reiss (12).

We have been particularly interested in the $\mathrm{pH}$ of the gastric content under various conditions. In the presence of free hydrochloric acid the $\mathrm{pH}$ is 3.0 or lower, and varies necessarily rather closely with the degree of free hydrochloric acid present. To the present, however, there have been very few observations on the $\mathrm{pH}$ of gastric contents showing no free hydrochloric acid. Under these circumstances, there may be a wide range of variation in $\mathrm{pH}-$ from 3.0 to 7.0 (neutrality) or above -in regard to which range ordinary determinations of gastric acidity give no information. It is noteworthy that in a small group of apparently normal individuals (about 4 per cent according to Bennett and Ryle) there is a persistent lack of free hydrochloric acid, yet these persons have no symptoms of gastric malfunction. It is conceivable that in these individuals in spite of the absence of free hydrochloric acid, the $\mathrm{pH}$ of their gastric contents might still be low enough (3.0 or 4.0) to be adequate (though not optimal) for peptic action. One of our anacidity patients exhibits this state of affairs. Case 17 (syphilis of the stomach) showed no free hydrochloric acid at any time. This was the only anacidity case in our series that showed reasonably good peptic activity. It was also the only case of anacidity that showed a pH lower than 5.5; the figures ranging between 3.5 and 4.0.

The only other observation on this point of which we have knowledge is that of Babbott, Johnston, Haskins and Shohl (13). It has long been known that in milk-fed infants there is usually no free hydrochloric acid in the gastric contents during the first year or so of life, yet there is good peptic activity. The above mentioned authors 
studied $\mathrm{pH}$ variations in infants ranging in age from three to nineteen months. In the normal children the range of $\mathrm{pH}$ was 3.2 to 5.0 , most of the figures being between 3.9 and 4.6. In our cases of true "achylia" (low peptic activity associated with achlorhydria) the $\mathrm{pH}$ was always 5.5 or above, most of them being between 6.0 and 7.0.

Numerous previous observations have been made on the chloride concentration in the gastric contents of normal persons and of patients with achlorhydria. Our findings in normal individuals fall within the same range as those of Wiener (14), Reisner (15) and Grund (16).

In patients with achlorhydria, which is not due to carcinoma, the chloride concentration has usually been found lower than normal. Grund and Wiener made their observations after a test meal. Strauss (17), in studying the efficiency of gastric resorption in cases of achlorhydria with pernicious anemia, found varying chloride concentrations in the fasting stomach. When the original concentration was low in the fasting content - below 40 milliequivalents - it rose progressively after the test meal to about that level or a little higher; when the concentration exceeded 80 milliequivalents in the fasting content, it fell after the test meal, through dilution. His studies were carried on over a period of forty-five minutes.

We have determined the chloride concentration in the fasting contents fourteen times in nine patients with achlorhydria. (See also tables $6,8,10,15,16$ and 17.) We found fasting chloride values that uniformly fell within the normal range. After the test meal, in seven observations on six cases of achlorhydria, there was invariably a decrease in the chloride concentration, for from fifteen to sixty minutes, whereas in patients with free hydrochloric acid, there was a distinct rise in chloride concentration after the test meal. This would suggest that in the anacidity cases dilution of the stomach contents had occurred by the test meal, and, in view of the continued fall in chloride concentration, by further dilution with a fluid low in chloride content (possibly a gastric secretion). There was a late rise in chloride concentration, but in only one instance did this rise reach or exceed the previous fasting level (experiment 12). 
R. A. KERN, E. ROSE AND J. H. AUSTIN

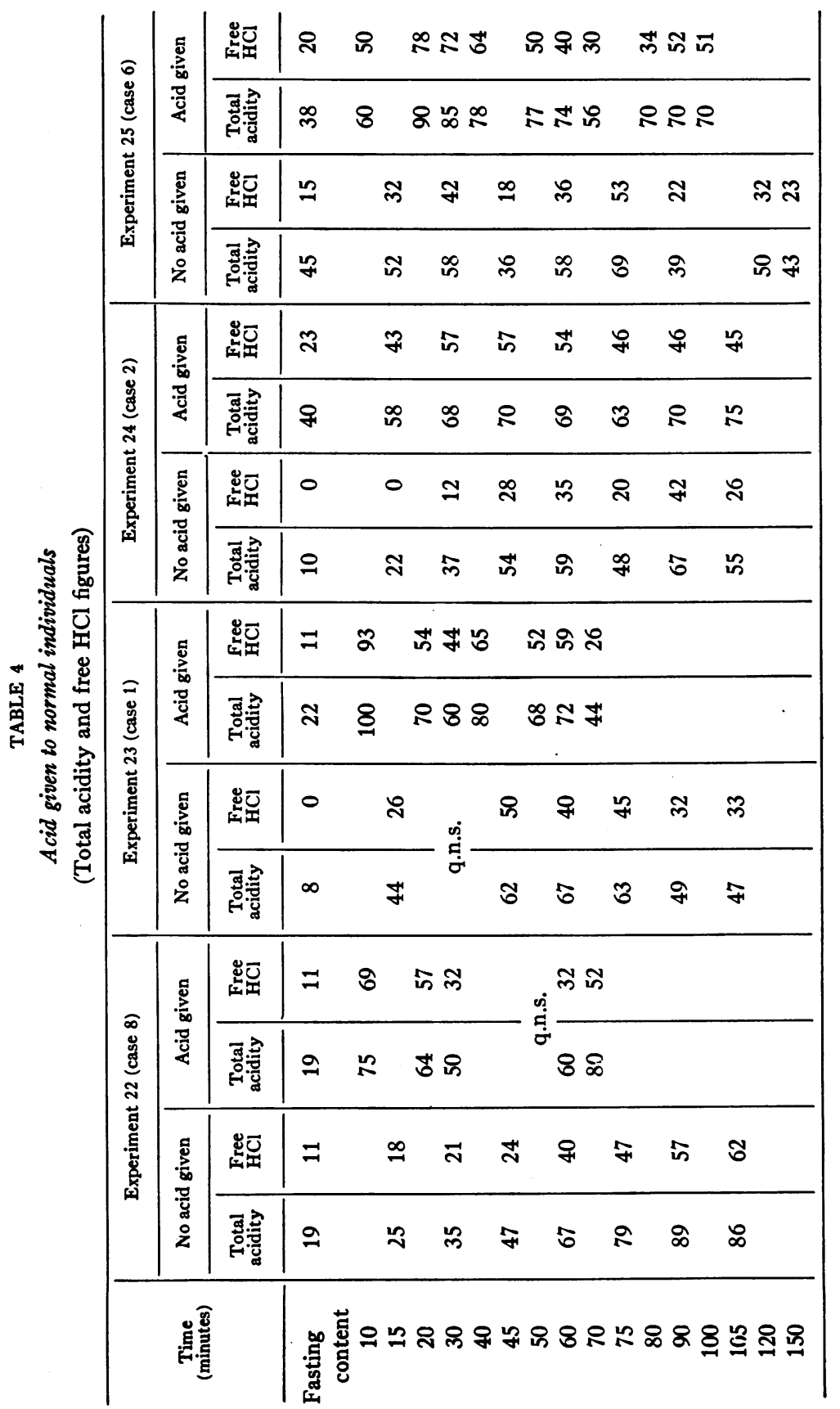




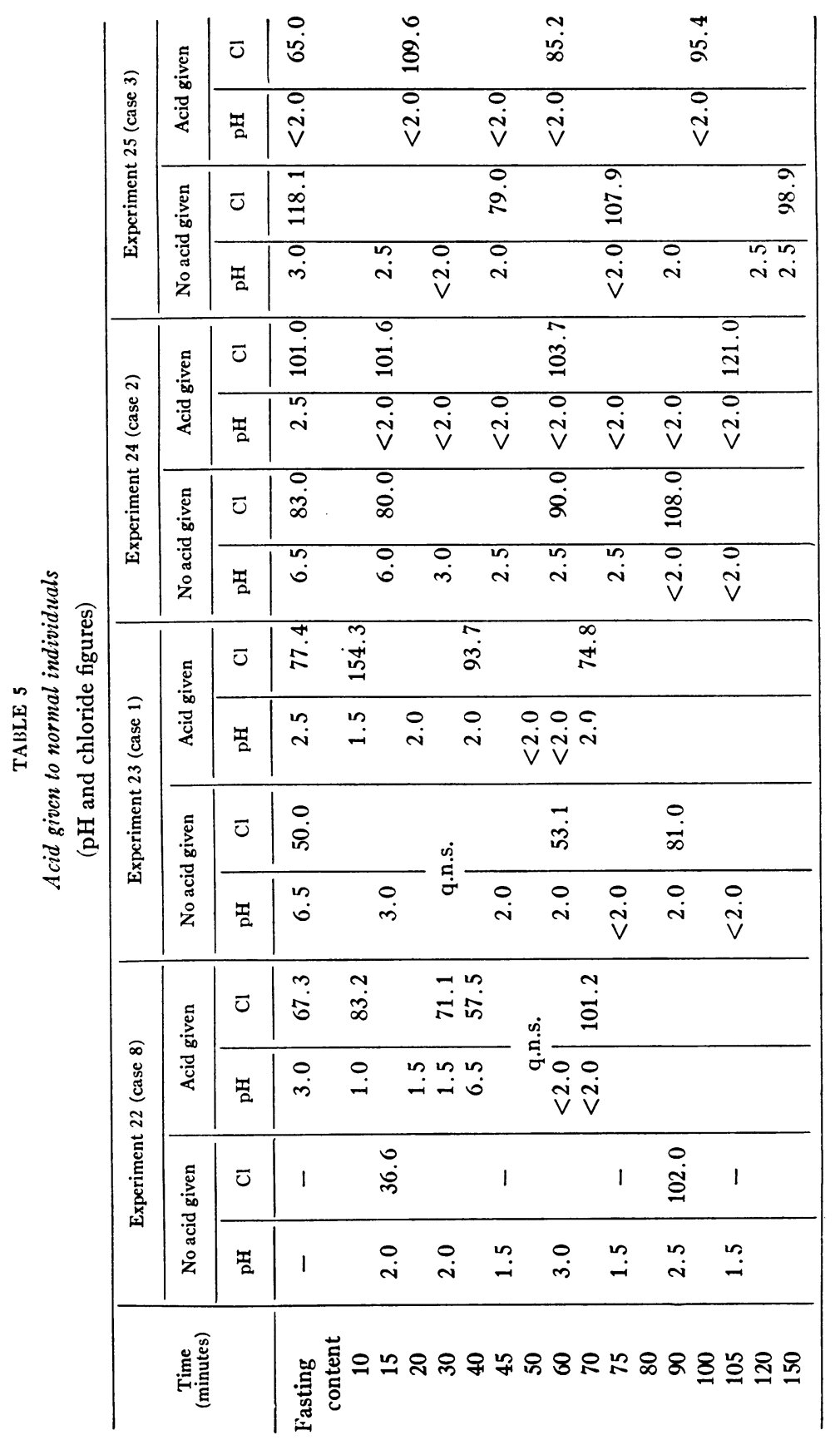


EFFECTS OF HYDROCHLORIC ACID ADMINISTRATION IN NORMAL INDIVIDUALS

Four subjects of the group with normal acidity were given dilute hydrochloric acid. The amount of acid administered in each case was the maximal concentration given later to subjects with achlorhydria. It is generally accepted that the highest concentration in which hydrochloric acid occurs free in the gastric juice is about 120 to 125 millimolar, or 0.43 to 0.45 per cent (Carlson (18)). It was thought inadvisable, therefore, to exceed this concentration in the administration of acid to patients, because of possible injury to the stomach. The maximum dose of acid given to any subject was $14 \mathrm{cc}$. of dilute hydrochloric acid (U. S. P.-11.5 per cent by weight) diluted to 360 cc. with water, the resultant mixture having a millimolar concentration of 120 . The four normal cases accordingly received $14 \mathrm{cc}$. of dilute U. S. P. hydrochloric acid diluted to $360 \mathrm{cc}$. with water. In each instance the stomach was first emptied of its fasting content; the test meal was then given and the acid mixture swallowed by the subject or introduced through the tube. Tables 4 and 5 record the results obtained, and, for ready comparison include the results obtained in the same subjects in the previous control observations.

Peptic activity was also tested in experiment 22 (case 2) and the results before and after acid administration were as follows:

Case 2. Peptic activity

\begin{tabular}{|c|c|c|}
\hline & No acid given & Acid given \\
\hline Fasting contents. & 2.8 & 3.3 \\
\hline 45 minutes....... & 3.3 & \\
\hline 60 minutes............... & & 3.0 \\
\hline 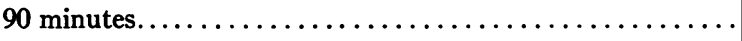 & 3.3 & 3.2 \\
\hline
\end{tabular}

The results of maximal administration of acid in these normal individuals may be summarized as follows:

1. Total acidity was increased, the increase being greatest within the first fifteen minutes, and persisting during thirty to sixty minutes, with little difference thereafter.

2. Free hydrochloric acid was greatly increased; the increase was again most marked in the first fifteen minutes and persisted a little longer than the increase in total acidity. 


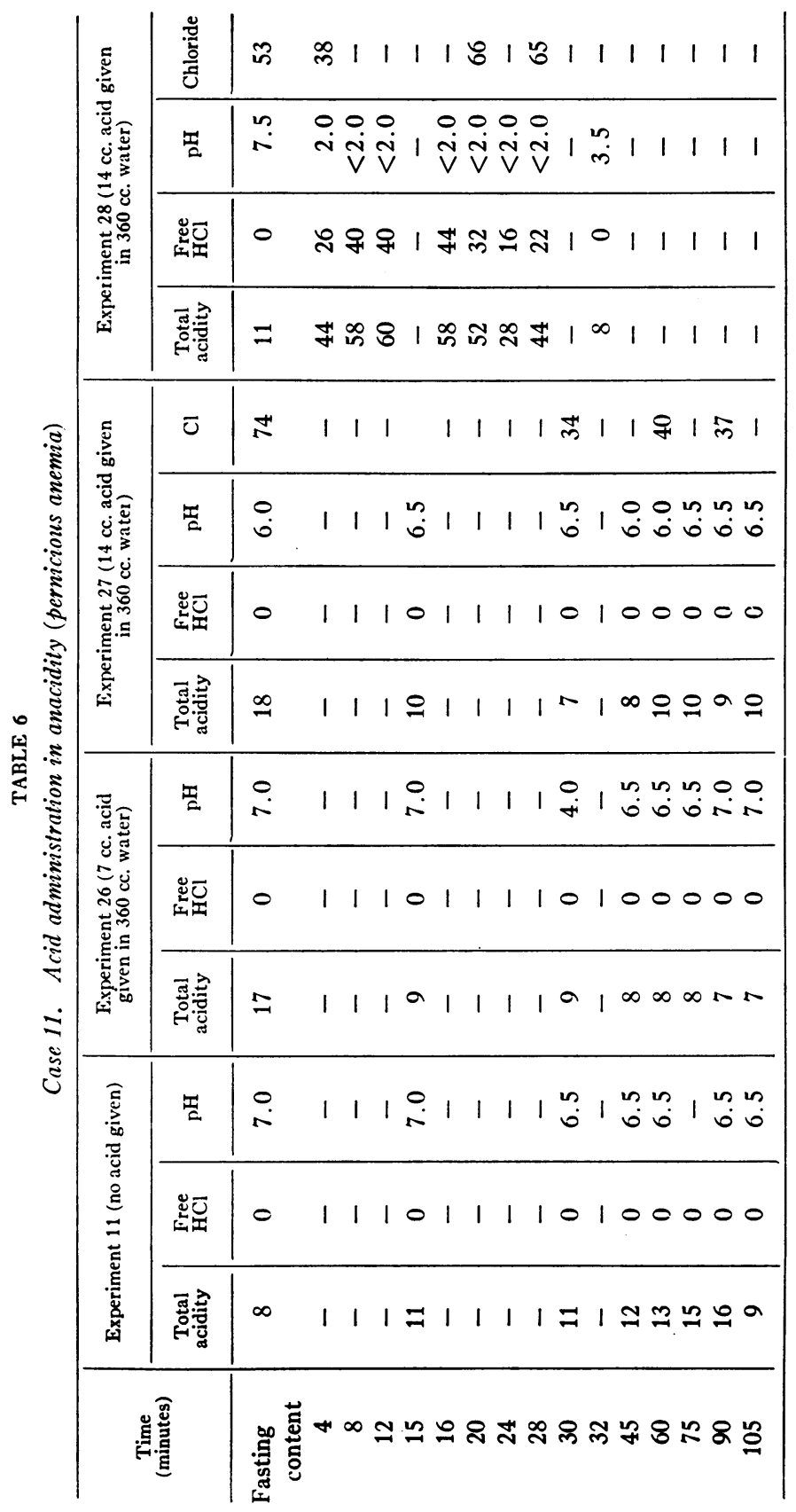


3. $\mathrm{pH}$ was decreased, the change tending roughly to parallel the increase in free hydrochloric acid.

4. The chloride content was definitely increased during the first hour in three out of four cases studied.

5. Peptic activity in the one case studied showed no change.

\section{EFFECTS OF HYDROCHLORIC ACID ADMINISTRATION IN PATIENTS WITH ACHLORHYDRIA}

Dilute hydrochloric acid was administered in amounts ranging from 1 to $14 \mathrm{cc}$. Fifteen observations were made on ten patients. (Eight of them had primary pernicious anemia, one syphilis of the stomach

\section{TABLE 7}

Case 11. Peptic activity

\begin{tabular}{c|c|c|c}
\hline ITime (minutes) & $\begin{array}{c}\text { Experiment } 26 \text { (7 cc. acid } \\
\text { given in } 360 \text { cc. water) }\end{array}$ & $\begin{array}{c}\text { Experiment 27 (14 cc. acid } \\
\text { given in } 360 \text { cc. water) }\end{array}$ & $\begin{array}{c}\text { Experiment 28 (14 cc. acid } \\
\text { given in } 360 \text { cc. water) }\end{array}$ \\
\cline { 2 - 3 } Fasting content & 2.1 & 1.6 & 2.0 \\
8 & & & 1.2 \\
15 & 2.1 & & \\
28 & & 1.6 & \\
30 & 1.3 & 1.6 & \\
60 & 2.1 & 2.0 & \\
90 & 2.1 & & \\
105 & 2.1 & & \\
\hline
\end{tabular}

and one a diaphragmatic hernia.) Samples of gastric contents were removed at intervals varying from two to fifteen minutes and, in a few instances, after the withdrawal of the last sample the stomach was washed out with water and the recovered water examined.

Tabulation of the results together with clinical notes on the individual cases follow.

\section{A. Pernicious anemia group}

Case 11. Mrs. L. H., aged 47, was admitted to the Medical Division of the University Hospital on August 25, 1924, and died February 4, 1925. Symptoms and findings on admission were characteristically those of primary pernicious anemia, with a blood count of $1,500,000$ red cells. Transfusion was followed by a remission of moderate degree, the red cells reaching 3,200,000. Thereafter there was a steady decline until death. Gastric studies were made immediately after the remission, the blood count falling during the period of our observation 


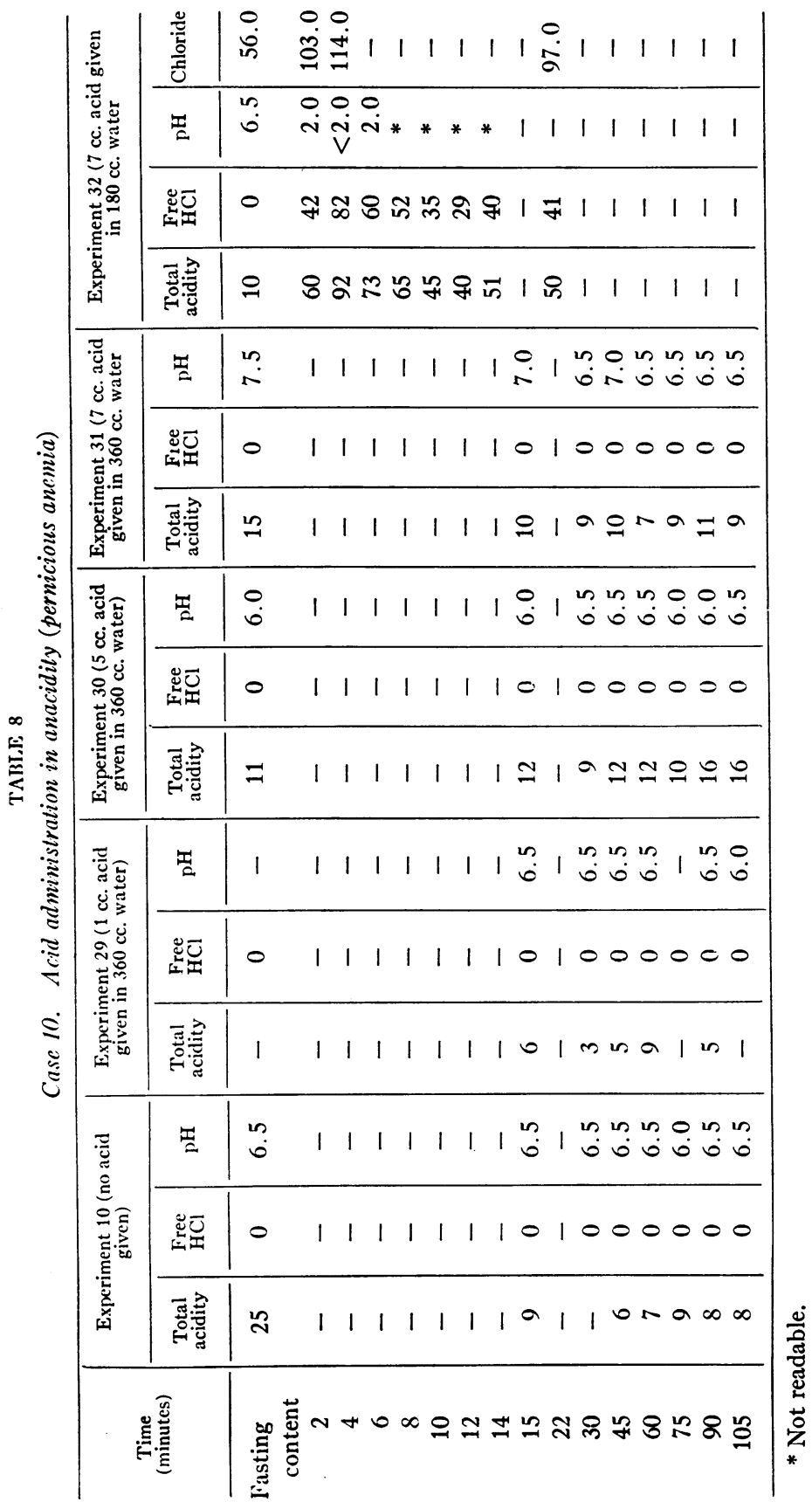


from $3,000,000$ to $2,400,000$. The diagnosis was confirmed at necropsy. (See tables 6 and 7.)

Case 10. Mr. W. R., aged 55, was admitted September 9 and discharged November 27, 1924. History and findings were characteristic of primary pernicious anemia, with advanced cord changes. The blood count varied from $1,700,000$ to $2,900,000$ red cells. Slight and transient improvement in the blood picture followed repeated transfusions. At the time of discharge he was growing rapidly worse, as shown by progressive anemia and increasing cord changes. The findings are given in tables 8 and 9.

Case 12. Mr. F. McC., aged 45, a patient with pernicious anemia but no cord changes, was studied from November 23 to December 3, 1924, during a period of

TABLE 9

Case 10. Peptic activity

\begin{tabular}{|c|c|c|c|c|c|}
\hline Time (minutes) & $\begin{array}{l}\text { Experiment } 10 \\
\text { (No acid given) }\end{array}$ & \begin{tabular}{|} 
Experiment 29 \\
$(1 \mathrm{cc}$. acid given \\
in $360 \mathrm{cc}$. water $)$
\end{tabular} & $\begin{array}{r}\text { Experiment } 30 \\
(5 \mathrm{cc} \text { acid given } \\
\text { in } 360 \mathrm{cc} \text {. water })\end{array}$ & $\begin{array}{l}\text { Experiment } 31 \\
\text { (7 cc. acid given } \\
\text { in } 360 \mathrm{cc} \text {. water })\end{array}$ & $\begin{array}{l}\text { Experiment } 32 \\
(7 \mathrm{cc} \text {. acid given } \\
\text { in } 180 \mathrm{cc} \text {. water })\end{array}$ \\
\hline $\begin{array}{l}\text { Fasting } \\
\text { content }\end{array}$ & - & - & - & 1.4 & 1.8 \\
\hline 15 & - & 1.9 & - & 1.4 & - \\
\hline 22 & - & - & - & - & 1.8 \\
\hline 30 & - & - & 1.6 & 1.4 & - \\
\hline 45 & & & 1.6 & 1.4 & - \\
\hline 60 & 1.6 & 2.2 & 1.6 & 1.9 & - \\
\hline 75 & & & 1.6 & 1.9 & - \\
\hline 90 & - & - & 1.6 & - & - \\
\hline
\end{tabular}

remission. He had been previously admitted to the hospital on March 10, 1924, with anemia of a most advanced degree, the blood count at that time showing 500,000 red cells. Considerable benefit was derived from transfusion, but the most marked improvement followed an attack of facial erysipelas a month after admission. The blood count on May 18 th was $3,200,000$ red cells. He was discharged and returned November 23 for further study. During this interval he continued in fairly good health and on readmission his red cell count was $3,400,000$. Treatment in the interval included the intermittent administration of dilute hydrochloric acid in $5 \mathrm{cc}$. doses with each meal. The findings in this case are shown in table 10.

Case 13. Mr. J. C., aged 26, was admitted to the hospital on December 2, 1924, and died February 20, 1925. He exhibited the characteristic clinical and laboratory findings of primary pernicious anemia, with confirmation of the diagnosis at necropsy. The splenomegaly, increased urobilin output, and slightly 
TABLE 10

Experiment 33. Case 12. Acid administration in anacidity (pernicious anemia)

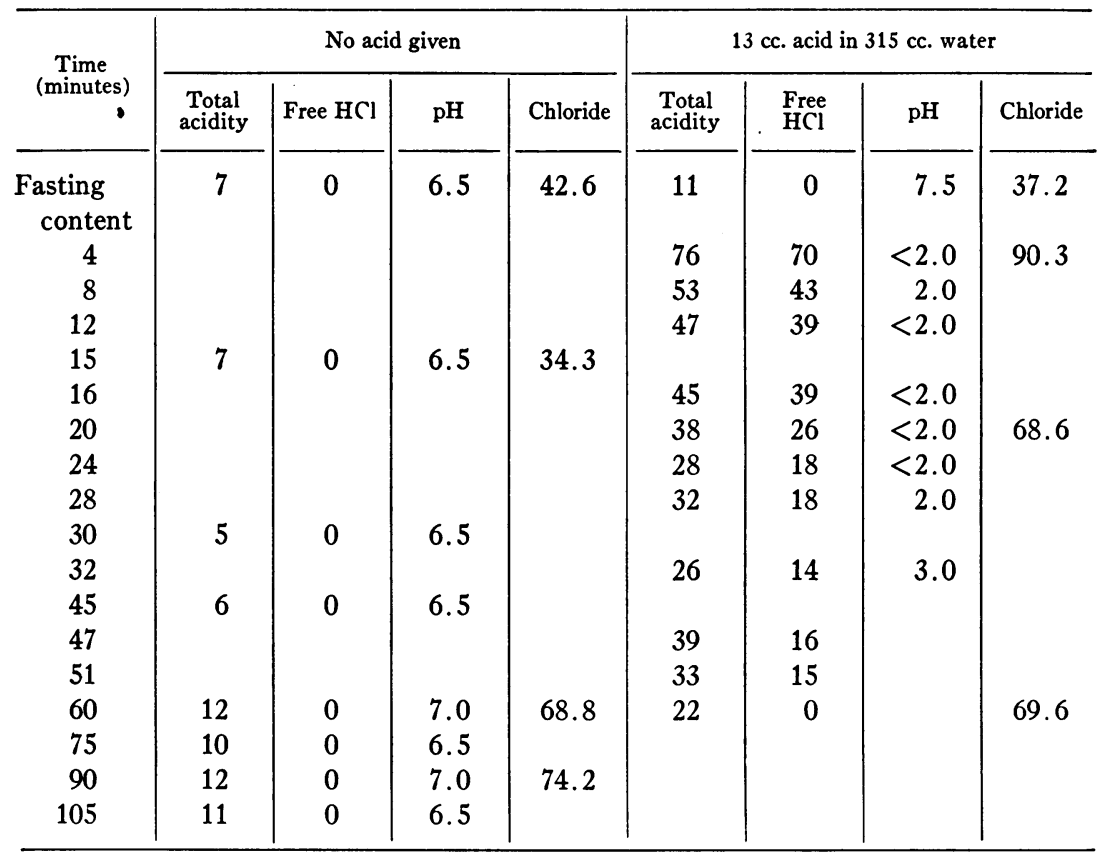

TABLE 11

Experiment 34. Case 13. Acid administration in anacidity (pernicious anemia)

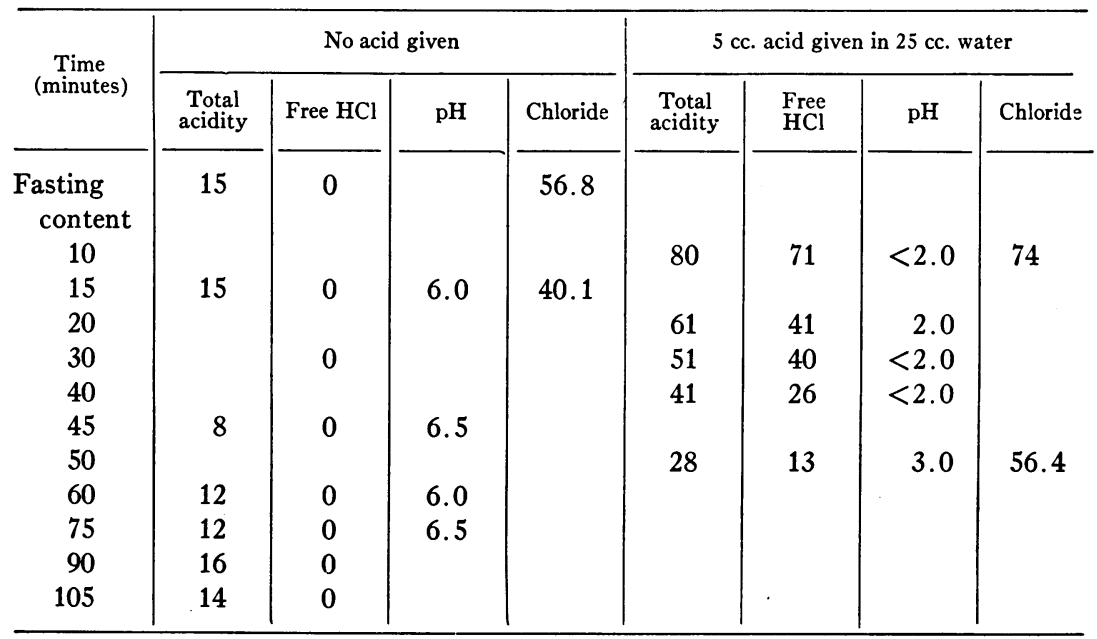


increased erythrocyte fragility, together with jaundice and a positive indirect Van den Bergh test pointed toward a hemolytic type of the disease. The anemia was of a severe degree and our studies were made during a period when the red cell count ranged between 730,000 and 820,000 . Subsequent transfusions caused only slight transient improvement. Our findings are shown in table 11.

Case 9. Mrs. S. B., aged 51, was admitted to the hospital on September 19th and discharged October 20,1924. The findings were typical of primary pernicious anemia. The blood count on admission was 2,700,000 and fell progressively to $1,800,000$ just prior to her discharge. The results of our gastric studies are given in table 12 .

TABLE 12

Experiment 35. Case 9. Acid administration in anacidity (pernicious anemia)

\begin{tabular}{c|c|c|c|c|c|c}
\hline $\begin{array}{c}\text { Times } \\
\text { (minutes) }\end{array}$ & \multicolumn{3}{|c|}{ No acid given } & \multicolumn{2}{|c}{1 cc. acid given in $360 \mathrm{cc}$ water } \\
\cline { 2 - 3 } & $\begin{array}{c}\text { Total } \\
\text { acidity }\end{array}$ & Free HCl & $\mathrm{pH}$ & $\begin{array}{c}\text { Total } \\
\text { acidity }\end{array}$ & $\begin{array}{c}\text { Free } \\
\mathrm{HCl}\end{array}$ & $\mathrm{pH}$ \\
\hline Fasting & 7 & 0 & 6.5 & 15 & 0 & 7.0 \\
content & & & & & & \\
15 & 17 & 0 & 6.5 & 10 & 0 & 6.0 \\
30 & 11 & 0 & 6.5 & 14 & 0 & 6.0 \\
45 & 16 & 0 & 6.0 & 26 & 0 & 6.0 \\
60 & 13 & 0 & 6.0 & 19 & 0 & 6.0 \\
75 & 10 & 0 & 6.0 & 29 & 0 & 6.0 \\
90 & 13 & 0 & 6.0 & 25 & 0 & 6.5 \\
105 & 17 & 0 & 6.5 & 20 & 0 & 6.5 \\
\hline
\end{tabular}

Case 15. Mr. C. H. has been a very interesting patient. At the age of thirtynine he was first admitted to the hospital on March 1, 1923, for a three weeks' stay, and has been under observation from time to time ever since. Illness had begun in 1921, and in 1923 there were characteristic phenomena of primary pernicious anemia together with paresthesias and the evidence of posterolateral sclerosis. His blood count at that time was $2,460,000$ and the hemoglobin 62 per cent. Then followed a remission that has persisted to date, the blood count on April 21, 1925, was 5,020,000, and the hemoglobin 97 per cent. The patient's strength has increased, his general condition is very good, and he is at active work. While the evidence of changes in the nervous system are still present, the paresthesias have almost disappeared. Since March, 1923, this patient has been intermittently taking dilute hydrochloric acid with meals in a dosage that in the past year has been between 2 and $3 \mathrm{cc}$. The gastric studies are given in table 13 . Attention is called to peptic activity which was quite low. 
Case 16. Mrs. C. T., aged 44, was admitted to the hospital on March 27, 1925. The symptoms and findings were those of primary pernicious anemia, together with cord changes. The blood count on admission was $1,340,000$ and the hemoglobin

TABLE 13

Experiment 36. Case 15. Acid administration in anacidity (pernicious anemia)

\begin{tabular}{c|c|c|c|c|c|c|c|c|c}
\hline $\begin{array}{c}\text { Time } \\
\text { (minutes) }\end{array}$ & \multicolumn{3}{|c|}{ No acid given } & \multicolumn{5}{|c}{$8 \mathrm{cc}$ acid given in 360 cc. water } \\
\cline { 2 - 8 } & $\begin{array}{c}\text { Total } \\
\text { acidity }\end{array}$ & Free HCl & $\mathrm{pH}$ & $\mathrm{pP} *$ & $\begin{array}{c}\text { Total } \\
\text { acidity }\end{array}$ & $\begin{array}{c}\text { Free } \\
\mathrm{HCl}\end{array}$ & $\mathrm{pH}$ & Chlorides & $\mathrm{pT} \dagger$ \\
\hline $\begin{array}{c}\text { Fasting } \\
\text { content }\end{array}$ & 9 & 0 (bile) & $7.5+$ & $<1.8$ & 12 & 0 & $7+$ & & \\
15 & 15 & 0 & 6.5 & $<1.8$ & 16 & 9 & 2.0 & 23.1 & 0 \\
30 & 5 & 0 & 6.5 & $<1.8$ & 15 & 4 & 2.5 & 26.7 & 0 \\
45 & 8 & 0 & 6.5 & $<1.8$ & 16 & 0 & 5.0 & & 0 \\
60 & 8 & 0 & 6.5 & $<1.8$ & 9 & 0 & 5.5 & & \\
75 & 11 & 0 & 6.0 & $<1.8$ & & & & & \\
90 & 10 & 0 & 6.5 & $<1.8$ & 7 & 0 & & & \\
105 & & & & & & & & & \\
120 & & & & & 4 & 0 & 7.0 & 12 & \\
\hline
\end{tabular}

${ }^{*} \mathrm{pP}=$ peptic activity.

$\dagger \mathrm{pT}=$ tryptic activity.

TABLE 14

Experiment 37. Case 16. Acid administration in anacidity (pernicious anemia)

\begin{tabular}{|c|c|c|c|c|c|c|}
\hline \multirow{2}{*}{$\underset{\text { (minutes) }}{\text { Time }}$} & \multicolumn{2}{|c|}{ No acid given } & \multicolumn{4}{|c|}{$8 \mathrm{cc}$. acid given in $360 \mathrm{cc}$. water } \\
\hline & $\begin{array}{c}\text { Total } \\
\text { acidity }\end{array}$ & Free $\mathrm{HCl}$ & $\begin{array}{c}\text { Total } \\
\text { acidity }\end{array}$ & Free $\mathrm{HCl}$ & $\mathrm{pH}$ & $\mathrm{pT}^{*}$ \\
\hline $\begin{array}{l}\text { Fasting } \\
\text { content }\end{array}$ & 8 & 0 & 8 & 0 & 7.5 & + \\
\hline 15 & 18 & 0 & 12 & 0 & 4.0 & \\
\hline 30 & 16 & 0 & 12 & 0 & 4.0 & \\
\hline 45 & q.n.s. & 0 & 12 & 0 & 5.0 & 0 \\
\hline 60 & q.n.s. & 0 & 12 & 0 & 5.0 & \\
\hline 75 & 8 & 0 & & & & \\
\hline 90 & 8 & 0 & 10 & 0 & 6.5 & \\
\hline 105 & 12 & 0 & 8 & 0 & 6.5 & \\
\hline
\end{tabular}

${ }^{*} \mathrm{pT}=$ tryptic activity.

30 per cent. The patient's condition has been little influenced by transfusion and at the time of this writing she is becoming steadily worse. No control studies were made on $\mathrm{pH}$, chlorides or ferments. The results of the gastric studies are stated in table 14 . 
Case 21. Mr. J. McC., aged 48, was admitted to the hospital on April 9, 1925. He dates his illness from July 1922, when he gave blood for a transfusion to his sister, who later died of primary pernicious anemia. The patient's symptoms and findings on admission were those of primary pernicious anemia of an advanced degree. The blood count has fluctuated between 670,000 and 1,250,000 and the hemoglobin between 21 and 30 per cent, a slight improvement following two transfusions. The patient's condition was so serious that only a single gastric study was made after acid administration and there are therefore no control figures. The findings are given in table 15 .

Five other patients with pernicious anemia were given $1 \mathrm{cc}$. each of dilute hydrochloric acid. In no instance was free hydrochloric acid found in the stomach on fractional analysis. As $\mathrm{pH}$, chloride and ferment studies were not made in these cases, we have omitted them from this report.

TABLE 15

Experiment 38. Case 21. Acid administration in anacidity (pernicious anemia). Four cubic centimeters acid given in $180 \mathrm{cc}$. water. (No control observations)

\begin{tabular}{|c|c|c|c|c|c|}
\hline Time (minutes) & Total acidity & Free $\mathrm{HCl}$ & $\mathrm{pH}$ & Chloride & $\mathrm{pT}^{*}$ \\
\hline $\begin{array}{l}\text { Fasting con- } \\
\text { tent }\end{array}$ & 5 & 0 & $7.5+$ & 30.2 & 2.9 \\
\hline 15 & 14 & 5 & 3.0 & 22.6 & 1.9 \\
\hline 30 & 13 & 5 & 3.0 & 245 & 10 \\
\hline 45 & 13 & 0 & 4.0 & 24.5 & 1.9 \\
\hline 60 & 6 & 0 & 6.5 & & \\
\hline 75 & 7 & 0 & 6.5 & & \\
\hline 90 & 8 & 0 & 6.5 & 33.5 & 1.9 \\
\hline 105 & 7 & 0 & 6.5 & & \\
\hline
\end{tabular}

* $\mathrm{pT}=$ tryptic activity.

\section{B. Non-anemic group}

Case 17. Miss E. G., aged 22, was admitted to the hospital on October 22d and discharged December 31, 1924. There was a history of indigestion and pain after meals at the onset six months before, followed by signs of increasing pyloric obstruction with vomiting, constipation and loss of weight. There were stigmata of syphilis, possibly congenital, in the form of old vitreous opacities and corneal changes, widespread choroiditis, and a general lymphadenopathy. The blood Wassermann on repeated occasions was strongly positive. The blood count was practically normal. Gastro-intestinal x-ray showed an organic obstruction at the pylorus, which was considered by Dr. Pancoast to be probably syphilis of the stomach, but with the possibility of carcinoma. She was given active antisyphilitic treatment, including salvarsan and iodide, with marked clinical im- 
provement. When last seen (April 1, 1925) she was symptom-free, her weight had increased from 81 pounds to 131 pounds, and fluoroscopic examination of the stomach showed definite improvement of the local lesion, which was still present

TABLE 16

Experiment 39. Case 17. Acid administration in anacidity (gastric syphilis)

\begin{tabular}{c|c|c|c|c|c|c|c|c|c|c}
\hline \multirow{2}{*}{$\begin{array}{c}\text { Time } \\
\text { (minutes) }\end{array}$} & \multicolumn{5}{|c|}{ No acid given } & \multicolumn{3}{|c}{14 cc. acid given in 363 cc. water } \\
\cline { 2 - 7 } & $\begin{array}{c}\text { Total } \\
\text { acidity }\end{array}$ & $\begin{array}{c}\text { Free } \\
\mathrm{HCl}\end{array}$ & $\mathrm{pH}$ & Chlorid & $\mathrm{pP}^{*}$ & $\begin{array}{c}\text { Total } \\
\text { acidity }\end{array}$ & $\begin{array}{c}\mathrm{Free} \\
\mathrm{HCl}\end{array}$ & $\mathrm{pH}$ & Chloride & $\mathrm{pP}^{*}$ \\
\hline $\begin{array}{c}\text { Fasting } \\
\text { content }\end{array}$ & 60 & 0 & 3.0 & 63 & 3.2 & 6 & 0 & 7.5 & 44 & 2.4 \\
15 & 64 & 0 & 3.0 & 62.1 & & 11 & 2 & 3.0 & 47 & 2.4 \\
30 & 30 & 0 & 3.0 & & & 20 & 8 & 3.0 & 47 & 2.4 \\
45 & 28 & 0 & 3.5 & & & 16 & 2 & 4.0 & & \\
60 & 26 & 0 & 3.5 & 38.9 & 3.2 & 18 & 0 & 4.0 & & 2.4 \\
75 & 26 & 0 & 3.5 & & & 17 & 0 & 4.0 & & \\
90 & 30 & 0 & 3.5 & & & 16 & 0 & 4.0 & & 1.9 \\
105 & 50 & 0 & 3.5 & 52.7 & & 17 & 0 & 4.0 & 65 & \\
\hline
\end{tabular}

${ }^{*} \mathrm{pP}=$ peptic activity.

TABLE 17

Experiment 40. Case 19. Acid administration in anacidity (idiopathic)

\begin{tabular}{c|c|c|c|c|c|c|c|c}
\hline $\begin{array}{c}\text { Time } \\
\text { (minutes) }\end{array}$ & \multicolumn{3}{|c|}{ No acid given } & \multicolumn{3}{|c}{7 cc. acid in 360 cc. water } \\
\cline { 2 - 8 } $\begin{array}{c}\text { Total } \\
\text { acidity }\end{array}$ & Free HCl & $\mathrm{pH}$ & Chloride & $\begin{array}{c}\text { Total } \\
\text { acidity }\end{array}$ & Free $\mathrm{HCl}$ & $\mathrm{pH}$ & Chloride \\
\hline $\begin{array}{c}\text { Fasting } \\
\text { content }\end{array}$ & 16 & 0 & 7.0 & 74.6 & 9 & 0 & 7.0 & 77.4 \\
10 & & & & & & & & \\
15 & 11 & 0 & 6.5 & 70.7 & 67 & 54 & 1.5 & 83.2 \\
20 & & & & & 60 & 50 & 2.0 & \\
30 & 9 & 0 & 6.5 & & 46 & 39 & 2.0 & \\
40 & & & & & 32 & 17 & 2.5 & 60.2 \\
45 & 8 & 0 & 7.5 & 52.0 & & & & \\
60 & 12 & 0 & 7.0 & 58.3 & & & & \\
75 & 9 & 0 & 7.0 & & & & & \\
90 & 7 & 0 & 7.0 & & & & & \\
105 & 9 & 0 & 6.5 & & & & \\
\hline
\end{tabular}

but no longer obstructive. The diagnosis of syphilis of the stomach seems amply warranted. Our observations were made in the second week of her stay in the hospital. The findings are given in table 16. 
Case 19. Mr. J. E., aged 54, was in the hospital from November 17th to December 23, 1924. There was a long history of constipation, for which an operation had been performed nine years previously, and later a second operation for supposed postoperative ahesions. Gastro-intestinal X-ray revealed a hernia of the stomach through the diaphragm, a finding which was confirmed by esophagoscopy. There was a persistant achlorhydria. Our findings are given in table 17.

\section{ANALYSIS OF TABLES VI TO XVII INCLUSIVE}

1. a. Free hydrochloric acid did not appear in the gastric contents after the administration of 1 cc. of dilute acid.

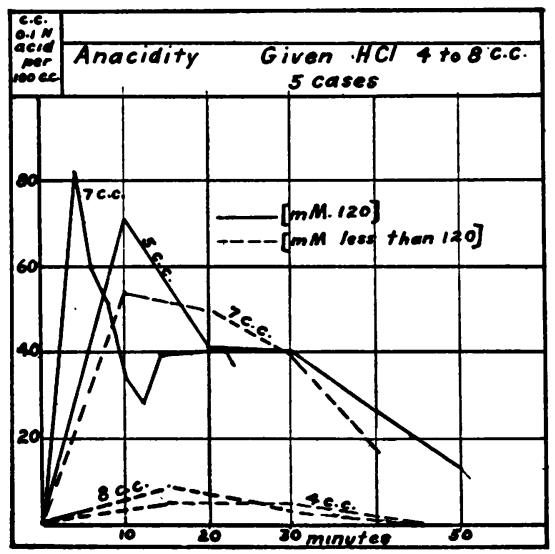

Fig. 1. Curves of Free HCl in Cases Numbers 10, 13, 15, 19 and 21 after RECEIVING 4 to 8 CC. OF ACID

$b$. The administration of 4 to $8 \mathrm{cc}$. of acid was followed in two cases (primary pernicious anemia; diaphragmatic hernia of the stomach) by an immediate rise of free hydrochloric acid to 71 and 54 milliequivalents respectively after ten minutes, free acid continuing to be present in diminishing amounts up to fifty minutes. A third case (primary pernicious anemia) showed free acid at two minute intervals for twenty-two minutes, the maximum being 82 milliequivalents at four minutes. Two other cases of primary pernicious anemia showed free acid at fifteen and thirty minutes. The curves are shown in figure 1. Three cases (primary pernicious anemia) showed no free acid on fifteen-minute testing. The concentration of the acid given 
to these patients was less than 120 millimolar in seven instances, and four of these failed to show free acid. In two instances the concentration of the acid given equaled 120 millimolar, and both of these patients showed free acid.

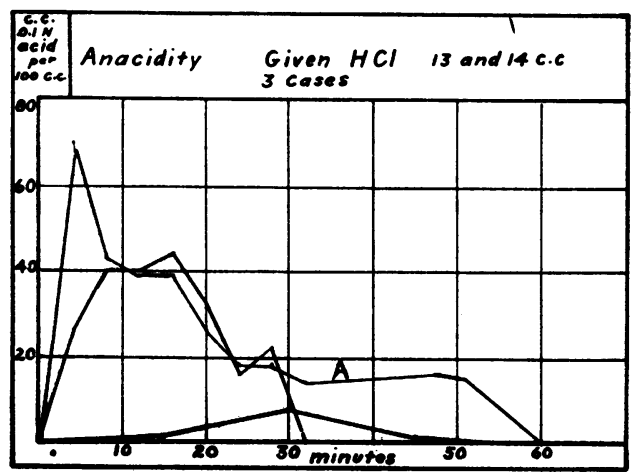

Fig. 2. Curves of Free $\mathrm{HCl}$ in Cases Numbers 11, 12 and 19 after ReceivING 13 To 14 CC. OF ACID

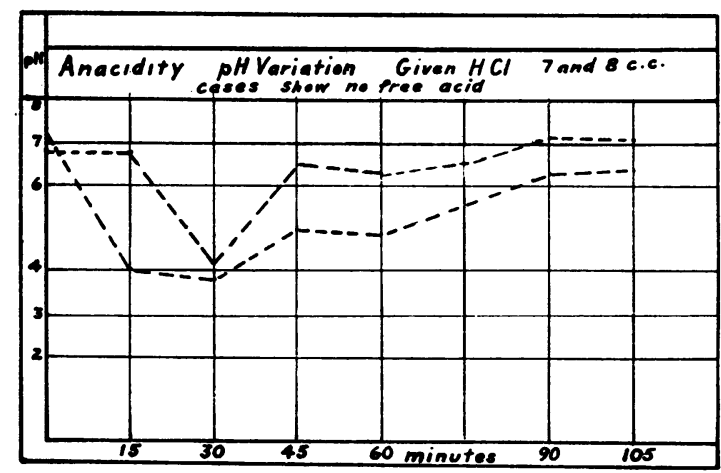

Fig. 3. pH Curves in Cases Numbers 11 and 16 after Receiving 7 and 8 cc. OF ACID RESPECTIVELY

c. The administration of 13 to $14 \mathrm{cc}$. of acid (millimolar concentration 120) in four instances was followed three times by the appearance of free acid, lasting from twenty-eight to fifty-one minutes (see fig. 2). The peak of the curve in two cases (primary pernicious anemia) occurred in the first specimen that was removed. A case of gastric syphilis showed a very slight rise in the free-acid curve. One 
case of pernicious anemia which showed free hydrochloric acid for twenty-eight minutes when the acid administered was given through the stomach tube and specimens removed every four minutes (curve A, fig. 2), failed to show free acid when the same amount of dilute acid was swallowed and specimens were removed every fifteen minutes.

2. Total acidity changes following acid administration roughly paralleled the changes in free hydrochloric acid.

3. The effects on the $\mathrm{pH}$ may be summarized as follows: When free hydrochloric acid was present after the administration of acid, the $\mathrm{pH}$ fell to 3.0 or below, the degree of change being roughly proportional to the degree of free hydrochloric acid present. When there was no free hydrochloric acid present, the $\mathrm{pH}$ in most instances was unchanged. In two cases, however, there was a fall in $\mathrm{pH}$ to values about 4.0 as shown in figure 3 . This type of change was never observed after the administration of less than $4 \mathrm{cc}$. of acid.

4. The results of our studies on the comparative chloride values do not lead to any definite conclusions. The most constant change was an immediate increase after acid administration, comparable to the increases in acidity.

5. In no instance was any effect on peptic activity noted.

6. Trypsin was present in the fasting contents of all cases studied except one, and tryptic activity was but little less than that in duodenal contents. In the one exception, the material obtained from the fasting stomach was chiefly mucus.

\section{DISCUSSION OF EFFECTS OF HYDROCLORIC ACID ADMINISTRATION IN ACHLORHYDRIA}

The effects of administration of hydrochloric acid on the various types of achlorhydria have been repeatedly studied in the past. In the pernicious anemia group the observations have been limited to the changes occurring in free and total acidity, and in bacteriacidal activity, with the general conclusion (Leo, Crohn, Shaw-previously cited) that $1 \mathrm{cc}$. of dilute hydrochloric acid produced no effect, and that it usually required at least $3 \mathrm{cc}$. to cause the appearance of free hydrochloric acid after a test meal. In carcinoma of the stomach, Fischer (19) found that larger amounts of hydrochloric acid were necessary to produce free acid in the gastric contents than were 
required in other types of achlorhydria. This he attributed to the buffer effect of protein split-products. In the cancer group the chlorides have also been studied, with the finding usually of higher values than in other forms of achlorhydria.

Little or no attention has been paid by previous observers to possible changes in the $\mathrm{pH}$ of the gastric contents in achlorhydria after the administration of hydrochloric acid. While the presence of free hydrochloric acid indicates a $\mathrm{pH}$ of 3.0 or below, yet a wide range of $\mathrm{pH}$ variation is possible in achlorhydria (from 3.0 to 7.0 or above), a range in which changes are of great importance in connection with peptic activity. It seemed to us possible that the administration of hydrochloric acid, although insufficient to produce free hydrochloric acid in the stomach contents, might nevertheless lower the $\mathrm{pH}$ to a range between 4.0 and 3.0. Such a $\mathrm{pH}$, even though not optimal, would materially enhance peptic activity.

In our experience, small doses of acid $(1 \mathrm{cc}$.) not only failed to produce free hydrochloric acid, but also did not appreciably lower the $\mathrm{pH}$. In an occasional case larger doses did cause a fall in $\mathrm{pH}$, but not to the point of appearance of free hydrochloric acid. It is conceivable, therefore, that in cases of anacidity gastric physiology may be favorably influenced at times by hydrochloric acid administration without the appearance of free acid, in that the action of the pyloric sphincter may be affected. The administration of hydrochloric acid in our series, however, did not in any instance increase peptic activity measured at optimal $\mathrm{pH}$; in other words, it did not stimulate pepsin secretion or prevent its destruction. Nor is this true only after single doses of acid. Cases 12 and 15 have been receiving from 2 to $4 \mathrm{cc}$. of dilute hydrochloric acid fairly constantly for nine and twelve months respectively, yet in neither instance was peptic activity at optimal $\mathrm{pH}$ greater at the end of that time than when treatment was begun. It would seem, therefore, that in primary pernicious anemia the diminished power to secrete pepsin cannot be restored by this therapy. A therapeutic corollary would be the administration routinely of pepsin as well as hydrochloric acid in attempting to reproduce normal gastric conditions.

The appearance of free hydrochloric acid after acid administration seems to depend on two factors: $(a)$ the nature and severity of the 
underlying cause of the achlorhydria, and (b) the amount and concentration of acid given. In general, our best results were obtained in cases of anacidity that were not due to primary pernicious anemia, and in cases of primary pernicious anemia in a state of remission. In the more amenable cases, 4 to $8 \mathrm{cc}$. of dilute acid, usually in a 120 millimolar concentration, produced free hydrochloric acid; in the severest cases, $14 \mathrm{cc}$. of acid at times failed or produced only transient free hydrochloric acid.

When free acid does appear after the administration of hydrochloric acid, the maximum concentration is found in the first specimen removed, and falls progressively thereafter. This is true both after single doses and after prolonged administration of acid. There is no evidence, therefore, to show that acid administration in achlorhydria is followed by increased secretion of acid by the gastric mucosa.

It was found quite feasible to administer doses of 4 to $8 \mathrm{cc}$. of acid over long periods of time. Given in tea or buttermilk and sipped during and after the meal, this amount of acid is easily taken by the patient. Larger doses are impracticable.

\section{THE FATE OF ORALLY ADMINISTERED HYDROCHLORIC ACID IN ACHLORHYDRIA}

It is remarkable with what rapidity hydrochloric acid, when administered orally, disappears or is neutralized in the gastric contents in patients with achlorhydria. A number of factors must be considered: neutralization by an alkaline gastric secretion; regurgitation of alkaline duodenal contents; swallowed saliva and mucus; absorption of acid from the stomach; and rapid passage onward into the duodenum. Our studies of the chloride concentration have shed no light on the problem. The constant presence of trypsin in the fasting gastric content proves that duodenal regurgitation at least plays a part.

\section{CONCLUSIONS}

1. The $\mathrm{pH}$ of the gastric content in achlorhydria may range from 3.0 to $7.0+$.

2. In our cases of primary pernicious anemia the $\mathrm{pH}$ was always 5.5 or higher-levels at which peptic activity is markedly depressed. 
3. In achlorhydria, not associated with primary pernicious anemia, the $\mathrm{pH}$ may in some cases be between 3.0 and 4.0 ; levels which permit of considerable (if not optimal) peptic activity, and consequently a fairly efficient gastric function.

4. The presence of trypsin in the fasting content of the stomach in achlorhydria points to duodenal regurgitation as a constant phenomenon in this condition.

5. The administration of dilute hydrochloric acid in cases of achlorhydria in a dosage of $1 \mathrm{cc}$. is not followed by the appearance of free hydrochloric acid and fails to produce any material change in the $\mathrm{pH}$ of the stomach contents.

6. After larger doses $(4$ to $14 \mathrm{cc}$.) the $\mathrm{pH}$ of the gastric contents is lowered: in some instances below 3.0 with the presence of the usual test for free hydrochloric acid, in others not below 3.0, and therefore not showing the usual test for free acid. In the latter case the change may nevertheless be sufficient to influence gastric function.

7. The effect produced by the acid varies with the nature and severity of the disease underlying the achlorhydria, and with the concentration of the acid administered.

8. In the treatment of achlorhydria doses of 4 to $8 \mathrm{cc}$. of dilute hydrochloric acid have been found practicable, adequate, and preferable to the usual dose of $1 \mathrm{cc}$.

9. The administration of hydrochloric acid, even though long continued, does not stimulate the secretion of pepsin or effect the spontaneous appearance of free hydrochloric acidin the stomachs of patients with achlorhydria.

10. In two cases of primary pernicious anemia remissions of nine and twelve months have co-existed with the continued administration of dilute hydrochloric acid in doses of $4 \mathrm{cc}$. Such acid therapy is worthy of further observation.

\section{BIBLIOGRAPHY}

1. Leo, H.: Die Salzsäure Therapie. Berlin, 1908.

2. Crohn, B. B.: Amer. Jour. Med. Sci., 1918, clvi, 656. Studies in Fractional Estimation of Stomach Contents. III. Effects of Hydrochloric Acid Therapy on the Acid Titer of the Stomach during Digestion.

3. Hurst, A. F.: Lancet, 1923, i, 111. Achlorhydria: Its Relation to Pernicious Anemia and Other Diseases. 
4. Shaw, M. E.: Quart. Jour. Med., 1924, xvii, 319. Achlorhydria and Hydrochloric Acid Therapy in Addison's (Pernicious) Anemia.

5. Vanderhoof, D.: Arch. Int. Med., 1923, xxxii, 958. The Etiological Relation of Achylia Gastrica to Combined Sclerosis of the Spinal Cord. The Relief of Symptoms following adequate Acid Therapy.

6. Bennett, T. I., and Ryle, J. A.: Guy's Hosp. Reports, 1921, lxxxi, 42. Studies in Gastric Secretion. V. A Study of Gastric Function based on Investigation of 100 Healthy Men by Means of the Fractional Method of Gastric Analysis.

7. Talbot, E. S.: Jour. Amer. Med. Assn., 1916, lxvi, 1849. The Examination of Normal Gastric Secretion by the Fractional Method.

8. Rehfuss, M. E., Bergeim, O., and Hawk, P. B.: Jour. Amer. Med. Assn., 1914, lxiii, 909. Fractional Study of Gastric Digestion with Description of Normal and Pathologic Curves.

9. Ivy, A. C., and Oyama, Y.: Amer. Jour. Physiol., 1921, lvii, 51. Studies on the Secretion of the Pars Pylorica Gastri.

10. Clark, W. M.: The Determination of Hydrogen Ions. Baltimore, 1920.

11. Itakura, Takeshi: Mit. a.d. Med. Fakultät d. Kaiserl. Univer. z. Tokyo, 1920, xxiv, 277. Pepsin und Trypsinverdauung, Modifikation der FuldGrosschen Methode.

12. Crohn, B. B., and Reiss, W.: Amer. Jour. Med. Sci., 1917, cliv, 857. Studies in Fractional Estimation of Stomach Contents.

13. Babbott, F. L., Jr., Johnson, J. A., Haskins, C. H., and Shohl, A. T.: Amer. Jour. Dis. Child., 1923, xxvi, 475. Hydrogen Ion Concentration of the Gastric Contents of Infants.

14. Wiener, H.: Arch. f. Verdauungskr., 1922, xxx, 309. Das gesammte Chlorid des Mageninhalts als differentiell-diagnostisches Kriterium.

15. Reissner, O.: Ztschr. f. klin. Med., 1902, xliv, 710. Ueber das Verhalten des Chlors im Magen und die Ursache des Salzsäuremangels bei Magenkrebsen.

16. Grund, G.: Deutsch. Arch. f. klin. Med., 1913, cix, 560. Ueber das festgebundene Chlor im Magensaft speziell bei Magencarcinom.

17. Strauss, H.: Ztschr. f. klin. Med., 1900, xli, 280. Untersuchungen über die Resorption und den Stoffwechsel bei Apepsia Gastrica mit besonderer Berücksichtigung der perniziösen Anämie.

18. Carlson, A. J.: Physiol. Rev., 1923, iii, 1. Gastric Secretion in Health and Disease.

19. Fischer: Deutsch. Arch. f. klin. Med., 1908, xciii, 98. Zur Kenntniss des carcinomatösen Mageninhaltes. 